IZA DP No. 6289

Economic and Spatial Determinants of Interregional Migration in Kazakhstan

Alisher Aldashev

Barbara Dietz

January 2012 


\title{
Economic and Spatial Determinants of Interregional Migration in Kazakhstan
}

\author{
Alisher Aldashev \\ ISE, Kazakh-British Technical University of Almaty \\ Barbara Dietz \\ Osteuropa-Institut Regensburg \\ and IZA
}

Discussion Paper No. 6289

January 2012

IZA

P.O. Box 7240

53072 Bonn

Germany

Phone: +49-228-3894-0

Fax: +49-228-3894-180

E-mail: iza@iza.org

Any opinions expressed here are those of the author(s) and not those of IZA. Research published in this series may include views on policy, but the institute itself takes no institutional policy positions.

The Institute for the Study of Labor (IZA) in Bonn is a local and virtual international research center and a place of communication between science, politics and business. IZA is an independent nonprofit organization supported by Deutsche Post Foundation. The center is associated with the University of Bonn and offers a stimulating research environment through its international network, workshops and conferences, data service, project support, research visits and doctoral program. IZA engages in (i) original and internationally competitive research in all fields of labor economics, (ii) development of policy concepts, and (iii) dissemination of research results and concepts to the interested public.

IZA Discussion Papers often represent preliminary work and are circulated to encourage discussion. Citation of such a paper should account for its provisional character. A revised version may be available directly from the author. 


\section{ABSTRACT}

\section{Economic and Spatial Determinants of Interregional Migration in Kazakhstan}

In this paper we analyze economic and spatial determinants of interregional migration in Kazakhstan using quarterly panel data on region to region migration in 2008-2010. In line with traditional economic theory we find that migration is determined by economic factors, first of all income: People are more likely to leave regions where incomes are low and more likely to move to regions with a higher income level. As predicted by gravity arguments, mobility is larger between more populated regions. Furthermore, distance has a strong negative impact on migration, indicating high migration related costs and risks. Assuming that high migration costs are caused by poor infrastructure, investments in public and social infrastructure should facilitate regional income convergence in Kazakhstan and improve living standards in depressed regions.

JEL Classification: J61, P36, R23

Keywords: interregional migration, Kazakhstan, gravity model

Corresponding author:

Barbara Dietz

Osteuropa-Institut Regensburg

Landshuter Str.4

93047 Regensburg

Germany

E-mail: dietz@osteuropa-institut.de 


\section{INTRODUCTION}

Since gaining independence in 1991 Kazakhstan experienced new migration dynamics. The huge emigration of citizens that prevailed in the 1990s faded out in later years and turned into a positive migration balance in 2004. Between 1991 and 2004 net migration in Kazakhstan accounted for a population loss of 2.04 million persons or nearly 13 percent of the population. To a considerable part this movement was related to the legacy of the Soviet labor market and nationality policy. The Soviet government had allocated its labor force within its vast territory according to central plans and certain ethnic groups had been forcefully relocated. After the break-up of the Soviet Union the newly introduced freedom of movement allowed people to return to their former homelands. Most persons who left Kazakhstan after independence either had originally gone there for work and job advancement (predominantly Russians) or because they had been forcefully resettled (mainly ethnic Germans).

Compared to the large and highly volatile external migration, interregional movements have been less pronounced and more stable: since independence they have on average involved approximately one percent of the population each year. Due to the alarming size of emigration from Kazakhstan in the early period after independence so far almost all attention has been on external migration and interregional migration has mostly been neglected. The disregard of internal mobility can also be attributed to data problems: time series on region to region migration have only recently been published and micro-data based on registration forms are unavailable for researchers. Accordingly, little is known about the patterns and determinants of interregional movements in Kazkakhstan, although its geographical and structural economic conditions point to the crucial role internal labor migration might play in regional adjustment processes.

Kazakhstan spans a vast territory (about 2.7 million sq. km; it is the 9th largest country in the world) which is inhabited by a relatively small population (nearly 16 million inhabitants) and hence is characterized by a low population density. Moreover, regional development has been persistently uneven across regions: on the one hand Astana (Kazkakhstan's capital since 1997), Almaty (the country's financial center and old capital), and oil-rich regions at the shores of the Caspian Sea have been developing fast; on the other hand depressed regions exist in the north and south. According to standard economic reasoning, these discrepancies in regional development should provide incentives for substantial internal migration movements. Such movements might also be expected to happen because internal migration barriers which existed throughout the 
Soviet system were abolished after Kazakhstan had become independent.

In this paper we analyze the economic and spatial determinants of interregional movements in Kazakhstan based on newly released region to region migration data. For 2008-2010 we study whether standard economic arguments such as differences in income and unemployment as well as factors put forward by spatial economics, i.e. population size and distance, explain the regional mobility of people.

The remainder of this paper is structured as follows: Section 2 describes the economic and migration development in Kazakhstan on the regional level. Section 3 presents the theoretical framework that motivates the gravity approach applied in our analysis and exemplifies empirical findings on internal migration movements. Section 4 introduces our data and methods, while Section 5 presents estimation results and Section 6 concludes.

\section{Regional ECONOMIC DEVELOPMENT AND MigRATION IN KAZAKHSTAN: STYLIZED FACTS}

Kazakhstan, which had for 70 years belonged to the Central Asian part of the Soviet Union, emerged as a newly independent country in 1991. After an administrative reform and the relocation of the country's capital from Almaty to Astana in 1997, the state was organized in 14 regions (oblasts) and 2 cities (Almaty and Astana). In the 1990s Kazakhstan experienced a severe economic and social crisis, but succeeded in reaching rapid economic growth in 2000-2007. This was the result of a booming energy sector and the implementation of market oriented reforms, such as price and trade liberalization, privatization, promotion of entrepreneurship and creation of the banking system (Wandel and Kazbogarova, 2009). Although Kazakhstan is engaged in diversifying its economy, growth continues to be largely driven by oil. The recent economic and financial crisis has resulted in a slow-down of the economy and revealed serious weaknesses in the banking system. Primarily supported by extractive and related industries, the Kazakh economy has returned to growth since the last quarter of 2009 (EBRD, 2010). Compared to other Central Asian post-Soviet economies, Kazakhstan stands out as a relatively stable and prosperous country. It is striking, though, that economic and social disparities between regions in Kazakhstan are high and do not seem to have decrease over time (Anderson and Pomfret, 2004; Dillinger, 2007).

In terms of economic output per capita Kazakhstans richest regions include Atyrau and Mangistau which are located in the West of the country at the shores of the Caspian Sea, where 
the majority of crude oil is extracted, and the two big commercial and administrative centers, Astana and Almaty (see table A.1 in the Appendix). The poorest regions are located close to Kazkakhstan's northern, southern, and eastern borders. They are the most populated and their share of rural population is highest (between $61 \%$ and $76 \%$ ). These regions are industrially underdeveloped and agriculture is the dominant sector of employment.

As shown in figure 1 the coefficient of variation in regional per capita GDP, a measurement of regional disparity, ranged from 0.7 to 0.8 in 2003-2010, which is extremely high in comparison to Eastern European and EU-15 countries. In the year 2003, the coefficient of variation in regional per capita GDP in Eastern Europe varied between 0.22 in Poland and 0.54 in Russia (Dillinger, 2007). In EU-15 countries regional economic variations (at the NUTS2 level) amounted to approximately 0.28 in the years between 1996-2004 (Monfort, 2008). The disparity between average nominal wages in Kazakhstan's regions is also considerably high and there is no evidence that it has reduced over time (see figure 1). This indicates that higher wage jobs are regionally concentrated.

Although Kazakhstan has experienced a remarkable economic growth since independence, poverty remains an acute problem for most of its regions. In this context it is particularly alarming that the two richest regions in terms of GDP per capita - the oil producing regions Mangistau and Atyrau - are characterized by an extraordinary high share of poor people. According to the Statistical Agency in Kazakhstan, the proportion of the population, whose income was below the subsistence minimum level, amounted to 22.6 percent in Mangistau and to 10 percent in Atyrau (see table A.1 in the Appendix). In case of Mangistau this was nearly three times higher than the national average (8.2 percent). Accordingly, oil production has contributed to a high regional GPD but failed to reduce regional poverty. 
Figure 1: Coefficient of variation in GDP per capita and wages*

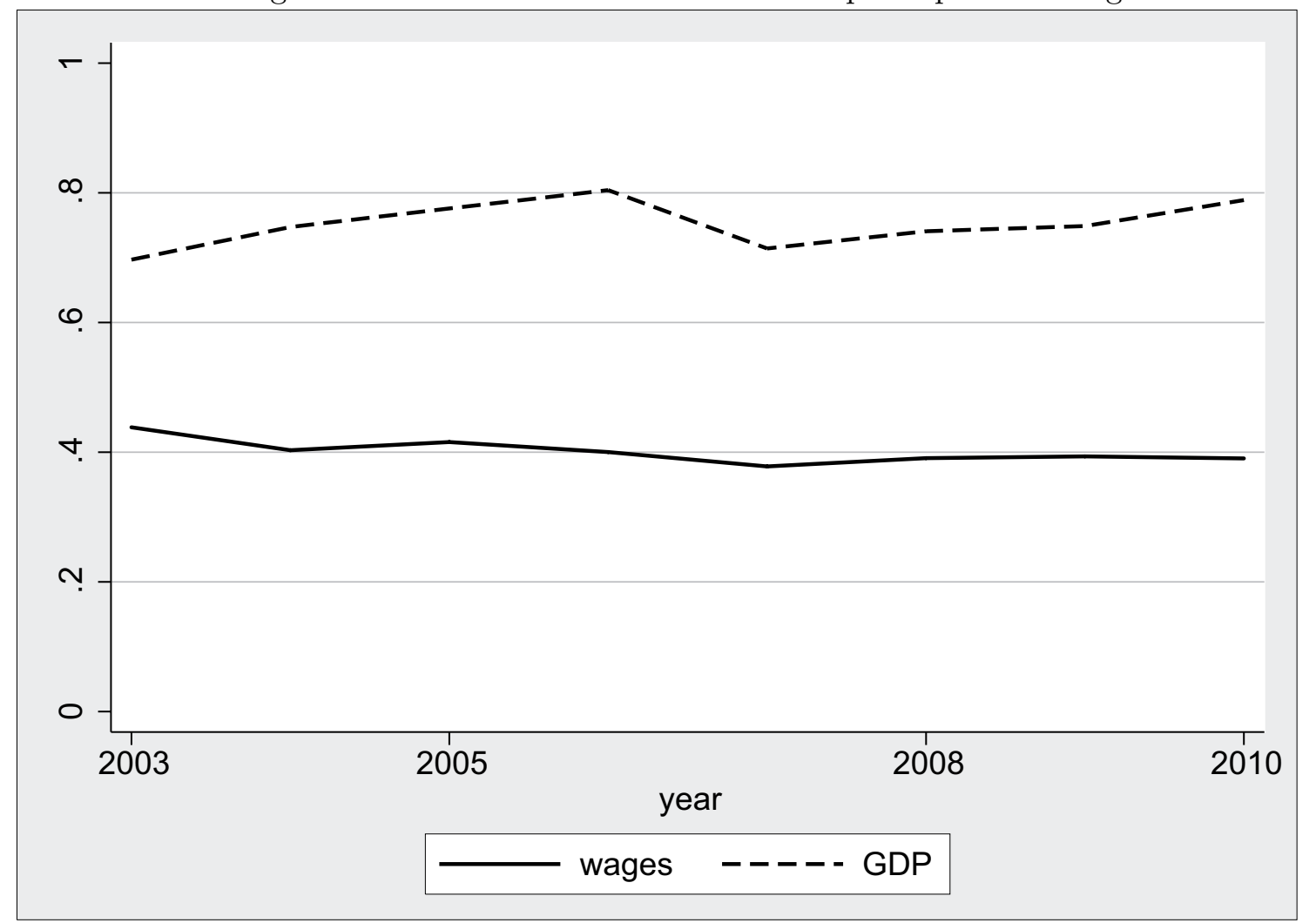

* Coefficient of variation is calculated as the ratio of the standard deviation to the mean. Authors' own calculations based on the data of the Statistical Agency of Kazakhstan

Source: Statistical Agency of Kazakhstan, authors' own calculation

Unemployment had been a considerable problem in the years following independence, but has since decreased and reached a level of 6.6 percent in 2009 (compared to 13.5 percent in 1999). In 2009 the unemployment rate varied between 6 percent in the Aktobe oblast and 7.47 percent in Almaty (see table A.1 in the Appendix). ${ }^{1}$ Over one-third of the national labor force was still employed in agriculture, producing only 6 percent of the national GDP (Wandel and Kazbogarova, 2009). According to Najman et al. (2008) in that year direct employment in the oil sector was under 50.000 people, even including employees working in the refining sector. This is equivalent to less than 1 percent of Kazakhstan's economically active population.

In the period between 2000 and 2010, interregional migration involved 138,750 persons on average per year (0.8 percent of the population)according to official data. In balance, the two big cities Almaty and Astana attracted nearly all internal migrants. Astana received people mostly from the comparatively close regions Aqmola, Karaganda, Kostanai, and East Kaza-

\footnotetext{
${ }^{1}$ The comparatively low interregional differences in unemployment rates are most likely due to measurement errors and under-reporting.
} 
khstan, while Almaty received most of its immigrants from Almaty oblast, Zhambyl, South and East Kazakhstan. Furthermore, a considerable exchange of people between the cities Almaty and Astana could be observed. These patterns indicate that distance plays an important role in determining internal movements in Kazkakhstan. In terms of magnitude, interregional mobility in Kazakhstan is close to interregional population flows in Russia, but much smaller than in the USA and Canada (Andrienko and Guriev, 2004).

\section{Determinants of Internal Migration Movements}

\subsection{Theoretical Framework}

Assume an economy with two regions A and B. Consider a resident of region A looking for a job. He randomly receives job offers from $\mathrm{A}$ and $\mathrm{B}$. The probabilities that offers from $\mathrm{A}$ and $\mathrm{B}$ arrive are given by $\lambda_{A}$ and $\lambda_{B}$, respectively. ${ }^{2}$ When the individual receives offers from both $\mathrm{A}$ and $\mathrm{B}$ he will move to region $\mathrm{B}$ if the wage in region $\mathrm{B}$ exceeds the wage in $\mathrm{A}$ by more than the migration cost. ${ }^{3}$

Suppose wages in A are drawn from a distribution function $F_{A}\left(w^{A}\right)$ with the mean $\mu_{A}$ and the variance $\sigma_{A}^{2}$ and wages in B drawn from $F_{B}\left(w^{B}\right)$ with the mean $\mu_{B}$ and the variance $\sigma_{B}^{2}$. Consider a distribution function $G(z)$, where $z=w^{B}-w^{A}$. The probability that the wage offer in $\mathrm{B}$ exceeds the wage offer in A by more than the migration cost is given by $1-G(\delta)$, where $\delta$ is the migration cost. This probability negatively depends on $\delta$, positively depends on $\mu_{B}$ and negatively on $\mu_{A}$, and positively on variances of the wage distribution in both $\mathrm{A}$ and B. ${ }^{4}$ The probability that the resident of A migrates to B is given as $\lambda_{B}(1-G(\delta))$, which is the conditional probability that the wage offer in $\mathrm{B}$ exceeds the wage offer in $\mathrm{A}$ by more than given that he receives an offer in $\mathrm{B}$.

The size of the migration flow from A to B can be given as:

$$
M_{A B}=S_{A} \cdot \lambda_{B}(1-G(\delta)),
$$

\footnotetext{
${ }^{2}$ It is possible to extend the model by considering endogenous arrival rates, for example when they depend on individual search intensities which are endogenously determined (see Aldashev, 2010, for example). The general results are however unchanged.

${ }^{3}$ Assuming the individual lives for 1 period. In a multiperiod model he moves to B if the present value of the job offer in $\mathrm{B}$ exceeds the present value of the job offer in A by more than the migration cost.

${ }^{4}$ Think of this probability as the truncated probability density function. For any constant $c, 1-F(c)>1-G(c)$ if the variance of the distribution $F(x)$ is greater than the variance of the distribution $G(x)$.
} 
It follows from equation 1 that the number of migrants from $\mathrm{A}$ to $\mathrm{B}$ depends positively on the number of job searchers in $\mathrm{A}$, that is $S_{A}$, the probability of receiving a job offer in $\mathrm{B}$, and the average wage in region $\mathrm{B}$ and negatively depends on the migration cost and the average wage in region $\mathrm{A}$.

It has to be noted that $\lambda_{B}$ and $\lambda_{A}$ are not directly observable. However the migration cost can be approximated by the function of the distance and the arrival rate of the job offers in region $\mathrm{B}$ by the function of the population size and the unemployment rate in B. ${ }^{5}$ The number of active searchers in region $\mathrm{A}$ is a function of the population size and the unemployment rate in A. Moreover, for the empirical model, the functional form in equation equation 1 is intractable. Therefore, one could use the gravity model of migration (see Lewer and Van den Berg, 2008) as an empirical simplification. And thus:

$$
m_{A B}=\alpha_{0}+\alpha_{1} \ln \left(P_{A}\right)+\alpha_{2} \ln \left(P_{B}\right)+\alpha_{3} \ln \left(w^{B}\right)+\alpha_{4} \ln \left(w^{A}\right)+\alpha_{5} \ln (\delta)+\alpha_{6} u^{A}+\alpha_{3} u^{B}+\epsilon,
$$

where $\epsilon$ is a random component and $\alpha_{1}, \alpha_{2}, \alpha_{3}$, and $\alpha_{6}$ are greater than zero, and $\alpha_{4}, \alpha_{5}$, and $\alpha_{7}$ are less than zero.

\subsection{Literature REVIEW}

The implications of the model outlined in the previous section are consistent with the neoclassical theory of labor migration which explains the movement of people by regional differences in expected incomes (i.e. income differences adjusted by unemployment probability) (Harris and Todaro, 1970). Accordingly, migration flows should be directed towards regions with comparatively higher incomes and lower unemployment rates. Extensions of this concept account for differences in other welfare and infrastructure variables, for example basic public services and environmental quality, to account for regional mobility in response to better living conditions (Lall et al., 2006). Additionally, Hatton and Williamson (2005) and Faini and Venturini (1994) point out that migration costs and risks, such as the costs of traveling, information and income losses, as well as the psychological costs of leaving family, friends and neighbors in the home region, are important for understanding internal migration movements in low income regions.

In general, the costs and risks of moving are increasing with distance, an aspect already formulated in the first formal framework analysing migration, the gravity model (Greenwood,

\footnotetext{
${ }^{5}$ More formally the arrival rate is the function which depends on the number of unemployed and available vacancies. Given the lack of information on the vacancies in Kazakhstan we take the arrival rate as the function of the unemployment rate.
} 
1995; Lee, 1966). Recently, Cushing and Poot (2008) have pointed to the high relevance of distance in explaining internal migration flows. They referred to the strong theoretical rationale of this concept in addition to the numerous empirical studies that showed its importance. Together with distance, the gravity concept refers to population size as a decisive force in shaping the dynamics of population mobility. Regions with large populations are expected to have the potential for sending big numbers of migrants, while they are also considered to attract more migrants because of larger markets. In a recent application of the gravity model to migration movements, Lewer and Van den Berg (2008) show that it provides a constructive framework to capture basic economic, spacial and ethno-cultural influences on population mobility.

The dynamics and the determinants of internal migration movements have repeatedly attracted the interest of economic research. This is related to the question if regional movements have the potential to mitigate regional disparities within economies. A basic finding so far is that internal migration is much higher in the United States and Canada than in Europe (Long, 1991; Bentivogli and Pagano, 1999; Coulombe, 2006). While in the United States internal movements have been identified to play an important role in reducing regional unemployment and wage differentials by shifting people from regions with low-productivity and high-unemployment to economically prospering ones, Fidrmuc (2004) did not find a corresponding pattern in East European countries. And even though research on internal migration in Italy indicates that relative per capita GDP and relative unemployment rates were the most important drivers for internal migration in that country between 1970 and 2002 (Piras, 2010), these movements were far too low to act as an equilibrating mechanism for regional imbalances. Concerning the role of unemployment in channeling interregional migration in Italy empirical results are controversial. In contrast to Piras (2010) who estimated a robust inverse relation between unemployment and the migration rate, Daveri and Faini (1997) did not discover a significant influence of unemployment on mobility, while Fachin (2007) pointed to a weak impact. In Great Britain relative unemployment and wages have been identified to influence regional mobility but the related regional adjustment processes are apparently very slow (Pissarides and McMaster, 1990). A similar nexus has been observed for Germany, where considerable welfare differences between East and West have not been mitigated by internal mobility (Decressin and Fatás, 1995).

The drivers of internal migration and its potential to support regional adjustment processes has also been explored in the context of transition and post-Soviet economies. Internal migration flows are often expected to act as an adaptation mechanism to shocks related to transition. 
For four East European countries (Poland, Hungary, the Czech Republic and Slovakia), Fidrmuc (2004) analyzed the factors that influenced internal mobility in the aftermath of economic transition, i.e. from 1992 to 1998. His research shows that high wages encouraged and high unemployment discouraged regional inflows as well as outflows, implying that the mobility of people was high in better-off regions while in poorer regions it was low. Accordingly internal movements did not flow from economically unsuccessful to successful regions. Furthermore the impact of wages and unemployment on internal migration flows was very small. Similar observations have been reported for Baltic countries (Hazans, 2003). Studies conducted in Russia provide a further illustration for interregional mobility in a transition context. Although regional disparities in Russia were high between 1992 and 1999, interregional migration flows were rather low. Nevertheless, richer regions with better employment chances and a better endowment of public goods attracted people while depressed regions experienced outflows (Andrienko and Guriev, 2004). This was also confirmed by a later study on region-to-region migration in Russia between 2000-2003 which discovered that well-off Moscow and surrounding regions in addition to resource-mining areas were popular destinations for internal movements (Kumo, 2005). Analyzing the question why regional mobility in Russia only marginally responded to regional welfare differences, Andrienko and Guriev (2004) proposed financial constraints to play a role. In their empirical analysis they found that an increase of incomes in the poorest regions encouraged out-migration, indicating that people had to earn a certain threshold income to be able to afford the move.

For Kazkakhstan no research on the determinants of internal migration movements have been conducted. However, in their study on migration between Kazakhstan and Russia Becker et al. (2005) showed that these movements responded to conventional economic variables and economic shocks such as the 1998 Russian financial crisis and relative exchange rate fluctuations.

\section{DATA AND METHODOLOGY}

\subsection{DATA}

For our analysis we use quarterly regional migration data between 16 administrative districts (oblasts) of Kazakhstan for the period 2008-2010. Migration data published by the Statistical Agency of Kazakhstan are collected by the local police authorities and are based on statistical coupons that have to be filled out upon registering or de-registering. Statistical coupons are only 
completed in case of permanent registration or de-registration (so-called propiska and vypiska) and thus the official migration statistics do not contain temporary migrants.

In total we have information on migration movements for 2,880 pairs of regions. We also use quarterly data on the average wage, income, unemployment rate, and population size of all 16 administrative districts.Wage is the monthly average nominal wage per employee. Income is defined as quarterly income per person including labor and non-labor income such as transfers and benefits. Incomes and wages are reported in the Kazakh national currency - Tenge. ${ }^{6}$ The unemployment rate is the share of unemployed in the labor force. Additionally, we calculated the distance between administrative centers (which are also the largest cities) in kilometers as a proxy for the distance between pairs of regions. We also measured the travel time between administrative centers using the Google route planner. Table 1 presents descriptive statistics for all mentioned variables.

Table 1: Descriptive statistics

\begin{tabular}{lrrrr}
\hline variable & mean & st.dev. & min & max \\
\hline migration flow & 173 & 394 & 0 & 4899 \\
income $(\mathrm{Tg})$ & 122,999 & 110,571 & 15,498 & 416,968 \\
wage $(\mathrm{Tg})$ & 68,403 & 27,559 & 35,132 & 152,241 \\
population & 984,684 & 506,678 & 390,531 & $2,510,395$ \\
unemployment rate & 6.3 & 0.6 & 5.0 & 8.2 \\
distance (km) & 1,543 & 777 & 177 & 3,681 \\
travel time (hours) & 20.8 & 11 & 2.6 & 53 \\
\hline
\end{tabular}

Source: Statistical Agency of Kazakhstan, authors' own calculation

It shows that the average population of a region is less than a million, while the average distance between regions is roughly $1,500 \mathrm{~km}$ or 21 hours travel time. A large variation in regional wages and especially in incomes can be observed. Although the correlation between migration flows and wage and income differentials is signifcant, figure 3 reveals that it is not very strong 2 .

\footnotetext{
${ }^{6}$ Currently 1 USD is worth roughly 147 Tenge
} 
Figure 2: Effect of wage and income differentials on migration

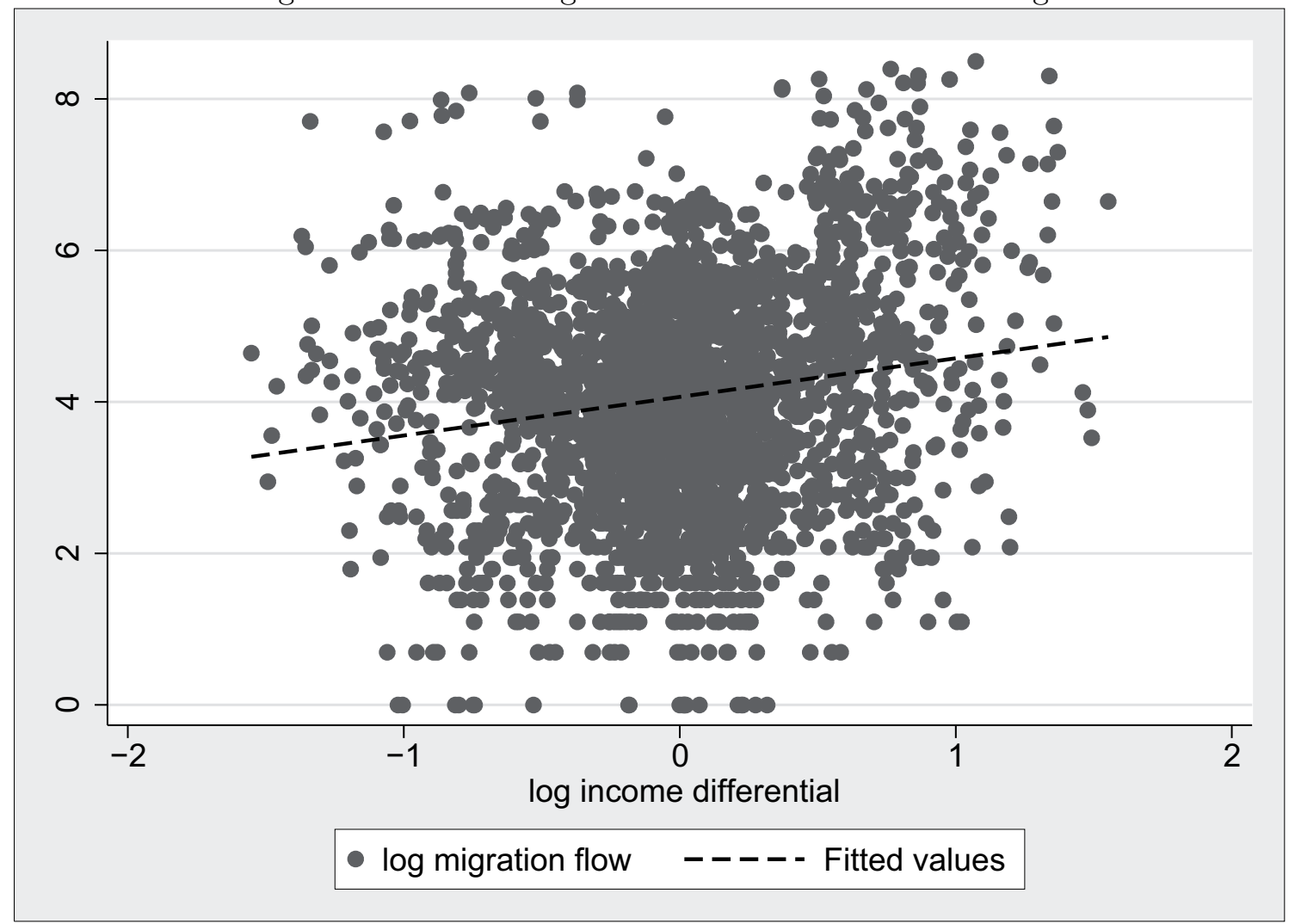

Source: Statistical Agency of Kazakhstan, authors' own calculation

\subsection{EMPIRICAL MODEL}

Based on the theoetical framework presented above, we use a so-called gravity model to estimate the determinants of interregional migration flows (see also Andrienko and Guriev, 2004; Etzo, 2008; Lall et al., 2006). After logarithmic transformation the gravity model for migration has the following general form:

$$
\log M_{i j t}=Z_{i t} \mathbf{B}+Z_{j t} \boldsymbol{\Gamma}+\alpha D_{i j}+\epsilon_{i j t}
$$

where $M_{i j t}$ is the migration flow from region $i$ to region $j$ at period $t, Z_{i t}$ and $Z_{j t}$ include covariates for the sending region and the receiving region, respectively, at period $t, D_{i j}$ is the distance factor between regions $i$ and $j, \epsilon_{i j t}$ is the error term, and $B, \Gamma$, and $\alpha$ are parameters to be estimated. The model can be generalized to include time and regional fixed effects that capture time invariant differences between regions such as economic resources, geographic and cultural variables. ${ }^{7}$

\footnotetext{
${ }^{7}$ One can of course argue that culture, that is traditions or attitudes, change over time. Nevertheless, given our short time frame we treat them as constant over time.
} 
In a spatial panel one might encounter spatial correlation and autocorrelation, that is contemporaneous correlation across spatial units and autocorrelation over time within each spatial unit. The Driscoll and Kraay (1998) method enables estimation of the covariance matrix which is robust to spatial and time autocorrelation (Hoechle, 2007). Consider the linear model:

$$
\begin{aligned}
& y_{i t}=X_{i t} \mathbf{B}+\epsilon_{i t}, \\
& i=1, \ldots, N, t=1, \ldots, T
\end{aligned}
$$

The variable $X$ is assumed to be uncorrelated with the error term. Even if the random component may exhibit autocorrelation and cross-sectional dependence, $B$ can be consistently estimated by OLS. As shown by Driscoll and Kraay (1998) the covariance matrix robust to autocorrelation and spatial correlation is given by

$$
V(\hat{B})=\left(X^{\prime} X\right)^{-1} \hat{S}_{T}\left(X^{\prime} X\right)^{-1}
$$

Here $\hat{S}_{T}$ is defined as

$$
\hat{S}_{T}=\hat{\Omega}_{0}+\sum_{j=1}^{m(T)} w(j, m)\left[\hat{\Omega}_{j}+\hat{\Omega}_{j}{ }^{\prime}\right],
$$

where $m(T)$ denotes the length of the lag up to which residuals may be autocorrelated and $w(j, m(T))=1-j /(m(T)+1){ }^{8}$ Moreover:

$$
\begin{aligned}
& \hat{\Omega}_{j}=\sum_{t=j+1}^{T} h_{t}(\hat{B}) h_{t-j}(\hat{B})^{\prime}, \\
& h_{t}(\hat{B})=\sum_{i=1}^{N(t)} h_{i t}(\hat{B}),
\end{aligned}
$$

where $h_{i t}(\hat{B})$ are moment conditions. Driscoll and Kraay (1998) showed that this method produces standard errors which are robust to general forms of spatial and time dependence.

\section{Estimation RESUlTS}

\subsection{BENCHMARK REGRESSIONS}

The estimation results for three different models are presented in table 2. Model 1 does not include fixed effects for origin and destination, models 2 and 3 do. But whereas model 2 contains wages, model 3 contains average income (which includes both labor and non-labor income).

\footnotetext{
${ }^{8}$ See Newey and West (1987).
} 
Table 2: OLS regression (dependent variable - log migration flow)

\begin{tabular}{|c|c|c|c|c|c|c|}
\hline \multirow[b]{2}{*}{ variable } & \multicolumn{2}{|c|}{ Model 1} & \multicolumn{2}{|c|}{ Model 2} & \multicolumn{2}{|c|}{ Model 3} \\
\hline & coefficient & significance & coefficient & significance & coefficient & significance \\
\hline log distance & -1.36 & $* * *$ & -1.34 & $* * *$ & -1.34 & $* * *$ \\
\hline log income destination & - & & - & & 0.16 & $* * *$ \\
\hline log income origin & - & & - & & -0.15 & $* *$ \\
\hline log population destination & 1.33 & $* * *$ & 0.86 & & 1.15 & $* *$ \\
\hline log population origin & 1.23 & $* * *$ & 1.43 & $* *$ & 1.31 & $* *$ \\
\hline log wage destination & 1.84 & $* * *$ & 0.86 & $* *$ & - & \\
\hline log wage origin & 0.89 & $* * *$ & -0.05 & & - & \\
\hline$u_{\text {destination }}$ & 0.67 & $* * *$ & 0.07 & & 0.07 & \\
\hline$u_{\text {origin }}$ & 0.49 & $* * *$ & 0.05 & & 0.04 & \\
\hline seasonal effects & Yes & & Yes & & Yes & \\
\hline year dummies & Yes & & Yes & & Yes & \\
\hline fixed effects origin & No & & Yes & & Yes & \\
\hline fixed effects destination & No & & Yes & & Yes & \\
\hline$R^{2}$ adjusted & 0.64 & & 0.78 & & 0.78 & \\
\hline$N$ & 2873 & & 2873 & & 2873 & \\
\hline
\end{tabular}

${ }^{*}$ significant at $10 \%$ level, ${ }^{* *}$ at $5 \%$ level, ${ }^{* * *}$ at $1 \%$ level

Across all three models, the effect of distance is almost identical. An increase in distance by one percent reduces the flow of migrants by roughly 1.3 percent. This elasticity is larger than those found by the literature for other countries such as Russia, the USA, and China which tend to be close to 1 in absolute value (Andrienko and Guriev, 2004). ${ }^{9}$ This might point at high travel costs in Kazakhstan possibly due to poor infrastructure. Another explanation might be that a high diversity in educational attainment and professional experience between more distant regions might preclude the transfer of human capital. Furthermore, internal movements over longer distances may be hampered by psychological costs of leaving family and friends and by high information costs. The effect of population size in both origin and destination is positive and similar to the results obtained for Russia (Andrienko and Guriev, 2004; Kumo, 2005). However, the effect of the population size in the destination region loses its significance in model 2. This could be due to the low variation of the population size over the three year span (2008-2010); thus the effect of the population size might partially be captured by regional fixed effects. In model 1 and 2 the wage in the destination region positively affects internal movements which is in line with the theoretical argumentation put forward by migration economics. At the same

\footnotetext{
${ }^{9}$ The strong impact of distance on internal migration in contemporary Kazakhstan stands in stark contrast to the comparatively low nexus between distance and population migration in the Soviet Union. As Mitchneck (1991) has pointed out this was the result of the politically motivated placement of people within the USSR.
} 
time, the effect of the wage in the origin is negligible. The elasticity of migration with respect to income is about 0.15 which is somewhat larger than the one obtained for Russia by Andrienko and Guriev (2004). Surprisingly, the effect of unemployment is positive for both origin and destination in model 1 while it appears to be insignificant in models 2 and 3 in the presence of regional fixed effects. Even without controlling for regional fixed effects the explanatory power of model 1 is substantial $\left(R^{2}=0.64\right)$. Introducing regional fixed effects in models 2 and 3 increases the explanatory power $\left(R^{2}=0.78\right)$.

We further estimated the model by controlling for autocorrelation as well as for spatial correlation. The estimates are presented in tables 3 and 4 .

Table 3: Generalized linear model (AR 4 autocorrelation structure)

\begin{tabular}{|c|c|c|c|c|c|c|}
\hline \multirow[b]{2}{*}{ variable } & \multicolumn{2}{|c|}{ Model 4} & \multicolumn{2}{|c|}{ Model 5} & \multicolumn{2}{|c|}{ Model 6} \\
\hline & coefficient & significance & coefficient & significance & coefficient & significance \\
\hline log distance & - & & -1.34 & *** & -1.34 & $* * *$ \\
\hline log travel time & -1.31 & $* * *$ & - & & - & \\
\hline log income destination & - & & - & & 0.14 & *** \\
\hline log income origin & - & & - & & -0.12 & *** \\
\hline log population destination & 0.42 & & 0.42 & & 0.78 & * \\
\hline log population origin & 0.72 & * & 0.73 & $*$ & 0.60 & \\
\hline log wage destination & 1.17 & $* * *$ & 1.17 & $* * *$ & - & \\
\hline log wage origin & -0.34 & & -0.34 & & - & \\
\hline$u_{\text {destination }}$ & 0.08 & $* *$ & 0.08 & $* *$ & 0.06 & $*$ \\
\hline$u_{\text {origin }}$ & 0.02 & & 0.02 & & 0.02 & \\
\hline$N$ & 2831 & & 2831 & & 2831 & \\
\hline seasonal effects & Yes & & Yes & & Yes & \\
\hline year dummies & Yes & & Yes & & Yes & \\
\hline fixed effects origin & Yes & & Yes & & Yes & \\
\hline fixed effects destination & Yes & & Yes & & Yes & \\
\hline
\end{tabular}

${ }^{*}$ significant at $10 \%$ level, ${ }^{* *}$ at $5 \%$ level, ${ }^{* * *}$ at $1 \%$ level

As in the OLS regressions the explanatory power of the model is high. We also find the elasticity of travel time or distance to range at about -1.3 . Furthermore, the effect of the population size in the origin and destination is positive and in most cases statistically significant. This confirms that people are more likely to move between more populated regions. While the income level in the origin has a negative influence on migration, it is positive in the destination region as has already been shown in the OLS regressions. This implies that people tend to leave regions where incomes are low and move to regions with higher income levels. Although the effect of the wage rate in the origin is negligible, the effect of the wage rate in the destination 
is positive. Consistent with the OLS regressions, unemployment does not seem to determine interregional migration flows.

Table 4: Linear model with autocorrelated errors across time and space (AR 4 autocorrelation structure)

\begin{tabular}{|c|c|c|c|c|c|c|}
\hline \multirow[b]{2}{*}{ variable } & \multicolumn{2}{|c|}{ Model 7} & \multicolumn{2}{|c|}{ Model 8} & \multicolumn{2}{|c|}{ Model 9} \\
\hline & coefficient & significance & coefficient & significance & coefficient & significance \\
\hline log distance & - & & -1.34 & *** & -1.34 & *** \\
\hline log travel time & -1.30 & ${ }^{* * *}$ & - & & - & \\
\hline log income destination & - & & - & & 0.16 & *** \\
\hline log income origin & - & & - & & -0.15 & *** \\
\hline log population destination & 0.86 & *** & 0.86 & $* * *$ & 1.15 & *** \\
\hline log population origin & 1.44 & *** & 1.43 & *** & 1.31 & *** \\
\hline log wage destination & 0.86 & ${ }^{* * *}$ & 0.86 & $* * *$ & - & \\
\hline log wage origin & -0.05 & & -0.05 & & - & \\
\hline$u_{\text {destination }}$ & 0.07 & & 0.07 & & 0.07 & \\
\hline$u_{\text {origin }}$ & 0.05 & & 0.05 & & 0.04 & \\
\hline seasonal effects & Yes & & Yes & & Yes & \\
\hline year dummies & Yes & & Yes & & Yes & \\
\hline fixed effects origin & Yes & & Yes & & Yes & \\
\hline fixed effects destination & Yes & & Yes & & Yes & \\
\hline$R^{2}$ & 0.77 & & 0.78 & & 0.78 & \\
\hline$N$ & 2873 & & 2873 & & 2873 & \\
\hline
\end{tabular}

${ }^{*}$ significant at $10 \%$ level, ${ }^{* *}$ at $5 \%$ level, ${ }^{* * *}$ at $1 \%$ level

\subsection{RobUstness CHECKS}

One might argue that it is not the nominal income or wage as used in our estimation but the real income or wage that potential migrants take into consideration when planning to move as price levels differ across regions. However, some variation in prices over time and across regions is captured in time dummies and regional fixed effects. To account for differences in regional price levels one might in principle also take the CPI to construct real wages or incomes. Although the Statistical Agency of Kazakhstan reports changes in CPI, this index captures price variation over time but not price variation across regions. Nevertheless, we try to overcome this problem by using data on the regional subsistence level reported by the Statistical Agency. The subsistence level varies across regions and over time and is reported on a quarterly basis beginning in 2009 . Prior to 2009 it is available on a yearly basis. We therefore defined log income deviations as $\ln \left(\right.$ income $\left._{r t}\right)-\ln \left(\right.$ subsist $\left._{r t}\right)$, that is the log deviation of the nominal income from the subsistence level for region $r$ in period $t$. For the year 2008 we assumed the yearly subsistence level reported 
by the Statistical Agency to be equal across all quarters. The results are reported in table 5 .

Table 5: Linear model (using income deviation from the subsistence level) with autocorrelated errors across time and space (AR 4 autocorrelation structure)

\begin{tabular}{|c|c|c|}
\hline \multicolumn{3}{|c|}{ Model $10^{a}$} \\
\hline variable & coefficient & significance \\
\hline log distance & -1.34 & *** \\
\hline log travel time & - & \\
\hline log income destination & 0.17 & $* * *$ \\
\hline log income origin & -0.15 & $* * *$ \\
\hline log population destination & 1.16 & $* * *$ \\
\hline log population origin & 1.30 & $* * *$ \\
\hline log wage destination & - & \\
\hline log wage origin & - & \\
\hline$u_{\text {destination }}$ & 0.07 & \\
\hline$u_{\text {origin }}$ & 0.04 & \\
\hline seasonal effects & Yes & \\
\hline year dummies & Yes & \\
\hline fixed effects origin & Yes & \\
\hline fixed effects destination & Yes & \\
\hline$R^{2}$ & 0.78 & \\
\hline$N$ & 2873 & \\
\hline
\end{tabular}

${ }^{\mathrm{a}}$ in Model $10 \log$ income is defined as log income deviation from the subsistence level

${ }^{*}$ significant at $10 \%$ level, ${ }^{* *}$ at $5 \%$ level, ${ }^{* * *}$ at $1 \%$ level

One can see that the estimates are virtually identical between models 9 and 10, confirming the results obtained earlier. Moreover, we estimated the model excluding flows from and to Astana as some movements to the new capital city might have been politically motivated. The main results remain however unchanged: people are more likely to move between larger regions and over smaller distances and migrants are attracted by the prospect of earning higher wages or incomes.

\section{Conclusions}

In this paper we analyzed the determinants of interregional migration in Kazakhstan using a quarterly panel for the years 2008-2010 for 16 administrative regions. We find that interregional movements in Kazakhstan can to a large extend be explained by economic and spatial factors.

First of all, we found that migrants are attracted by higher wages or incomes. The elasticity of migration to income is about 0.15 . If wages are used instead of incomes to represent earnings 
in the destination then a 1 percent growth in wages in the destination increases migration by between 0.8 and 1.8 percent. We did not find any significant effect of the unemployment rate on migration. Wages in the origin do not seem to impact population movements either. However, higher incomes in the origin reduce the migration probability. Regions with a larger population are more likely to send and likewise more likely to receive migrants.

The elasticity of migration to distance is about -1.3 . This is larger in absolute value than what has been found for other countries, for example Russia, the USA, and China, and points at higher migration related costs and risks in Kazakhstan. Thus, an equalization of regional disparities or convergence might take long time. This finding has political relevance as one could argue that investment in public and social infrastructure might facilitate regional income convergence and improve living standard in depressed regions. 


\section{REFERENCES}

Aldashev, A. (2010). Search across locations and commuting decision. In F. Caroleo and F. Pastore (eds.), The Labour Market Impact of the EU Enlargement: A New Regional Geography of Europe?, Heidelberg: Physica Verlag, pp. 227-245.

Anderson, K. and Pomfret, R. (2004). Spatial inequality and development in Central Asia. Research Paper No. 2004/36, World Institute for Development Economics Research.

Andrienko, Y. and Guriev, S. (2004). Determinants of interregional mobility in Russia: Evidence from panel data. Economics of Transition, 12 (1), 1-27.

Becker, C., Musabek, E., Seitenova, A. and Urzhumova, D. (2005). The migration response to economic shock: Lessons from Kazakhstan. Journal of Comparative Economics, 33 (1), 107-132.

Bentivogli, C. and Pagano, P. (1999). Regional disparities and labour mobility: the Euro-11 versus the USA. Labour, 3 (3), 737-60.

Coulombe, S. (2006). Internal migration, asymetric shocks, and interprovincial economic adjustment in Canada. International Regional Science Review, 29 (2), 199-223.

Cushing, B. and Poot, J. (2008). Crossing boundaries and borders: Regional science advances in migration modelling. Papers in Regional Science, 83, 317-338.

Daveri, F. and Faini, R. (1997). Where do migrants go? Oxford Economic Papers, 51 (4), 595-622.

Decressin, J. and Fatás, A. (1995). Regional labour market dynamics in Europe. European Economic Review, 39, 1627-1655.

Dillinger, W. (2007). Poverty and Regional Development in Eastern Europe and Central Asia. Chief Economists Regional Working Paper Series Vol. 2, No.1.

Driscoll, J. and KraAy, A. (1998). Consistent covariance matrix estimation with spatially dependent panel data. The Review of Economics and Statistics, 80 (4), 549-560.

EBRD (2010). Transition report 2010: Recovery and reform, European Bank for Reconstruction and Development. http://www.ebrd.com/pages/research/publications/flagships/ transition.shtml. 
Etzo, I. (2008). Internal migration: a review of the literature. MPRA paper No. 8783, Munich Personal RePEc Archive.

FACHIN, S. (2007). Long-run trends in internal migrations in Italy: A study in panel cointegration with dependent units. Journal of Applied Econometrics, 22, 401-428.

Faini, R. and Venturini, A. (1994). Migration and Growth: The Experience of Southern Europe. Discussion Paper No. 964, Center for Economic Policy Research.

FidRMUC, J. (2004). Migration and regional adjustment to asymmetric shocks in transition economies. Journal of Comparative Economics, 32 (2), 230-247.

Greenwood, M. (1995). Human migration: Theory, models and empirical studies. Journal of Regional Science, 25, 521-544.

Harris, J. and Todaro, M. (1970). Migration, unemployment, and development: A two-sector analysis. American Economic Review, 60 (1), 126-142.

Hatton, T. and Williamson, J. (2005). What fundamentals drive world migration? In G. Borjas and J. Crisp (eds.), Poverty, International Migration and Asylum, PalgraveMacmillan, pp. 15-38.

Hazans, M. (2003). Determinants of Inter-Regional Migration in the Baltic Countries. Working Paper No. B17-2003, ZEI.

Hoechle, D. (2007). Robust standard errors for panel regressions with cross-sectional dependence. Stata Journal, 7 (3), 281-312.

Kumo, K. (2005). Inter-regional population migration in Russia: Using an origin-to-destination matrix. Post-Communist Economies, 19 (2), 131-152.

Lall, S., Selod, H. and Shalizi, Z. (2006). Rural-Urban Migration in Developing Countries: A Survey of Theoretical Predictions and Empirical Findings. Policy Research Paper No. 3915, World Bank.

LEe, E. (1966). A theory of migration. Demography, 3, 47-57.

Lewer, J. and VAn Den Berg, H. (2008). A gravity model of immigration. Economic Letters, 99 (1), 164-167. 
Long, L. (1991). Residential mobility differences among developed countries. International Regional Science Review, 14, 133-47.

Mitchneck, B. (1991). Geographical and economic determinants of interregional migration in the USSR: 1968-1985. Soviet Geography, 32 (3), 168-189.

Monfort, P. (2008). Convergence of EU regions. Measures and evolution. Directorate-General for Regional Policy, Working Papers No. 01.

Najman, B., Pomfret, R. and Raballand, R. (2008). The Economics and politics of Oil in the Caspian Basin. Central Asia Research Forum. New York: Routledge.

NeWey, W. and West, K. (1987). A simple, positive semi-definite, heteroskedasticity and autocorrelation consistent covariance matrix. Econometrica, 55, 703-708.

Piras, R. (2010). Internal Migration Across Italian regions: Macroeconomic Determinants and Accommodating Potential for a Dualistic Economy. Working Paper 2010.115, Fondazione Eni Enrico Mattei.

Pissarides, C. and McMaster, I. (1990). Regional migration, wage and unemployment : empirical evidence and implications for policy. Oxford Economic Papers, 42 (4), 812-831.

Wandel, J. and Kazbogarova, B. (2009). Kazakhstan: Economic Transformation and Autocratic Power. Country Brief No. 4, Mercatus Policy Series. 


\section{A Appendix}

Table A.1: Regional economic indicators of Kazakhstan (2009)

\begin{tabular}{lrrrrrrr}
\hline & $\begin{array}{r}\text { area } \\
\text { (Tsd. sq. km) }\end{array}$ & $\begin{array}{r}\text { population } \\
\text { (Tsd.) }\end{array}$ & $\begin{array}{r}\text { regional } \\
\text { immigration }\end{array}$ & $\begin{array}{r}\text { regional } \\
\text { emigration }\end{array}$ & $\begin{array}{r}\text { GRP } \\
\text { per capita }\end{array}$ & $\begin{array}{r}\text { unemploy- } \\
\text { ment rate }\end{array}$ & $\begin{array}{r}\text { poverty } \\
\text { rate* }\end{array}$ \\
\hline Kazakhstan & 2724.9 & 15,925 & 171,051 & 171,051 & 1068.0 & 6.6 & 8.2 \\
Aqmola & 146.2 & 740 & 8,362 & 14,948 & 709.3 & 6.9 & 5.9 \\
Aktobe & 300.6 & 716 & 1,357 & 5,450 & 1193.1 & 6.0 & 6.3 \\
Almaty oblast & 224 & 1,680 & 22,938 & 22,437 & 460.3 & 6.4 & 15.5 \\
Atyrau & 118.6 & 508 & 3,397 & 3,173 & 3881.6 & 6.1 & 10.0 \\
West Kazakhstan & 151.3 & 622 & 2,282 & 3,410 & 1324.2 & 6.3 & 8.2 \\
Zhambyl & 144.3 & 1,038 & 7,064 & 14,140 & 336.3 & 6.5 & 4.8 \\
Karaganda & 428 & 1,349 & 8,710 & 9,365 & 1123.5 & 6.1 & 3.9 \\
Kostanai & 196 & 888 & 3,735 & 6,772 & 815.3 & 6.3 & 6.8 \\
Kyzyl-Orda & 226 & 684 & 4,729 & 7,617 & 937.4 & 6.6 & 10.4 \\
Mangistau & 165.6 & 436 & 6,481 & 3,225 & 2542.5 & 7.1 & 22.6 \\
South Kazakhstan & 117.3 & 2,405 & 7,756 & 21,913 & 384.8 & 6.6 & 11.7 \\
Pavlodar & 124.8 & 750 & 3,577 & 4,719 & 1150.8 & 6.4 & 6.2 \\
North Kazakhstan & 98 & 646 & 3,220 & 6,711 & 625.5 & 6.3 & 7.3 \\
East Kazakhstan & 283.2 & 1,418 & 5,756 & 12,285 & 693.6 & 6.4 & 6.6 \\
Astana city & 0.7 & 662 & 42,150 & 9,956 & 2075.2 & 6.6 & 3.9 \\
Almaty city & 0.3 & 1,385 & 39,537 & 24,930 & 2293.1 & 7.7 & 3.0 \\
\hline & & & & & &
\end{tabular}

* share of the population with an income below the subsistence minimum level

Source: Statistical Agency of Kazakhstan 